\title{
Epithelium-specific ets transcription factor 2 upregulates cytokeratin 18 expression in pulmonary epithelial cells through an interaction with cytokeratin 18 intron 1
}

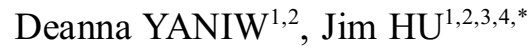 \\ ${ }^{1}$ Programme in Lung Biology Research and the Canadian Institutes of Health Research Group in Lung Development, \\ Hospital for Sick Children, Toronto, Canada M5G 1 X8. \\ ${ }^{2}$ Institute of Medical Science, University of Toronto, Toronto, Canada M5S 1A1. \\ ${ }^{3}$ Departments of Paediatrics, University of Toronto, Toronto, Canada M5S $1 \mathrm{Al}$. \\ ${ }^{4}$ Laboratory Medicine and Pathbiology, University of Toronto, Toronto, Canada M5S $1 \mathrm{Al}$.
}

\begin{abstract}
The role of Ese-2, an Ets family transcription factor, in gene regulation is not known. In this study, the interaction between Ese-2 and cytokeratin 18 (K18) intron 1 was characterized in lung epithelial cells. Reporter gene assays showed Ese-2 was able to upregulate K18 intron 1 enhanced reporter gene expression by approximately 2 -fold. We found that full length Ese-2 did not bind DNA strongly, therefore truncated versions of the protein, containing the ETS domain or Pointed domain, were created and tested in electrophoresis mobility shift assays. Multiple interactions between the ETS domain and putative DNA binding sites within K18 intron 1 were observed, which led to the determination of a possible Ese-2 DNA binding consensus sequence. These experiments suggest that Ese-2 could play a role in the regulation of K18 expression in lung epithelial cells.
\end{abstract}

Keywords: transcription factor, epithelial cells, cytokeratin 18, airway, gene regulation.

\section{INTRODUCTION}

V-ets, the first member of the Ets (E26 transformation-specific) transcription factor family, was discovered in 1984 in the avian virus E26 [1]. Since then, more than 30 Ets family members have been identified $[2,3]$. These proteins are expressed mainly in hematopoietic cells [4, 5], however some are also expressed in epithelial cells [6-11]. Ets factors are known to play roles in skeletal development, haematopoiesis, neural synapse formation, immunomodulation, metastasis, cellular proliferation and differentiation, and apoptosis [12-14]. Some members of this family have also been implicated in tumorigenesis [15-18].

Ets factors contain a conserved ETS DNA-binding (ETS) domain of 85 amino acids, which recognizes a core sequence of 5'-GGA(A/T)-3' in the ETS binding site (EBS) of target gene(s) [16-20]. Additional characteristics,

\footnotetext{
*Correspondence: Jim HU

Tel: 01-416-813-6412; Fax: 01-416-813-5771

Email: jhu@sickkids.on.ca
}

such as the MAPK sites within PEA3 [21], the phosphorylation site within Ets-1 [22], or the Pointed (PNT) domain (a protein-binding domain) in Ets-1 [23], aid in target gene recognition and/or protein-protein interactions.

Recently, Ese-2, a member of the ESE subfamily of Ets factors, has been recognized as an asthma candidate gene [24], and its expression is correlated with that of the gene encoding maspin, a tumor suppressor protein [25]. Little is known, however, about the role of Ese-2 in gene regulation. Under normal physiological conditions, Ese-2 and other members of the ESE subfamily are expressed solely in epithelial cells. Human Ese-2 and its mouse homolog, Elf5, have an amino acid identity of $95 \%$ [11], and both have an expression pattern that is restricted to differentiated keratinocytes and glandular epithelium [6]. The ETS domain of Ese-2, which recognizes a 5'-GGAA-3' core EBS, is located at the C-terminus of the protein $[6,11]$. Ese-2 also contains a PNT domain, which is located at the N-terminus. Although the PNT domain is distinct to other Ets factors, it represents a specific category within the SAM family of protein-binding domains. Many Ets factors require proteinprotein interactions [26, 27], and some Ets proteins, such 
as Ets-1, Ets-2, Erg, Fli-1, GABPa, Tel, PntP2 and Yan, contain a PNT domain $[28,29]$, which is involved in protein-protein interactions [29].

Target genes of Ese-2 have also not been identified, however more than 200 genes have been identified as target genes for other Ets factors, one of which is the human cytokeratin 18 (K18). K18 is an intermediate filament expressed solely in differentiated epithelial cells. The first intron of $K 18$, which contains multiple putative EBSs, three negative regulatory elements, and a strong enhancer, has been shown to play an important role in regulating expression of the gene [30-33]. Other Ets factors, such as Ets2, a member of the ETS subfamily, have been shown to interact with regions of the first intron of K18 cooperatively with cofactors such as AP-1 [32]. This interaction causes the upregulation of $K 18$ gene expression. The expression pattern of $K 18$ and the regulatory properties of the first intron make the $K 18$ gene ideal for investigating the transcriptional regulatory capabilities of Ese- 2 .

The aim of this study was to gain information on the biological function of Ese-2. In particular, we aimed to investigate the interaction between Ese- 2 and the intron of a target gene and to identify the effect of this interaction on gene expression. We show that Ese-2 upregulates K18 gene expression through specific interactions within EBSs in the regulatory first intron of the gene.

\section{MATERIALS AND METHODS}

\section{Plasmid constructions}

Ese-2 coding regions were isolated from the I.M.A.G.E. Consortium [LLNL] cDNA clone 3584025 [34], BC012424, using PCR. The following primers were used in the PCR: Ese-2 Forward, 5'CAGGATCCCCACCACTTGTCTTC-3' (BamHI site underlined), Ese-2 Reverse, 5'-GTATGTCGACCATCAGAGTTTCTCTTC-3' (SalI site underlined), Ese-2-ets Forward, 5'-ACGCGGATCCAAAGACTATGC-3' (BamHI site underlined), and Ese-2-pnt Reverse, 5'-CGGTCGACATAGTCTTTGATGG-3' (SalI site underlined). Ese-2 Forward and Ese-2 Reverse were used to isolate the full length Ese-2 coding sequence, which was then cloned into pET28a (Novagen, Germany) to create the bacterial expression construct $\mathrm{pET} 28 \mathrm{a} \cdot \mathrm{Ese}-2$, and into pcDNA3 (Invitrogen, California) to create the mammalian expression construct pcDNA3 Ese-2. Ese-2 Reverse and Ese-2-ets Forward were used to isolate 369 bp of the 3'end of Ese-2, encoding the ETS domain, which was then cloned into pET28a and pcDNA3 to create the plasmids pET28a Ese-2-ets and pcDNA3 Ese-2-ets, respectively. Ese-2 Forward and Ese-2-pnt Reverse were used to isolate 435 bp of the 5'-end of Ese-2, encoding the PNT domain, which was then cloned into pET28a and pcDNA3 to create the expression constructs pET28a.Ese-2-pnt and pcDNA3 Ese-2-pnt, respectively.

\section{Cell culture, transfection, and reporter gene assays}

Monolayers of A549 lung carcinoma cells (ATCC CCL 185) were grown in Dulbecco's Modified Eagle Medium (Invitrogen, California) supplemented with $10 \%$ fetal bovine serum. Monolayers

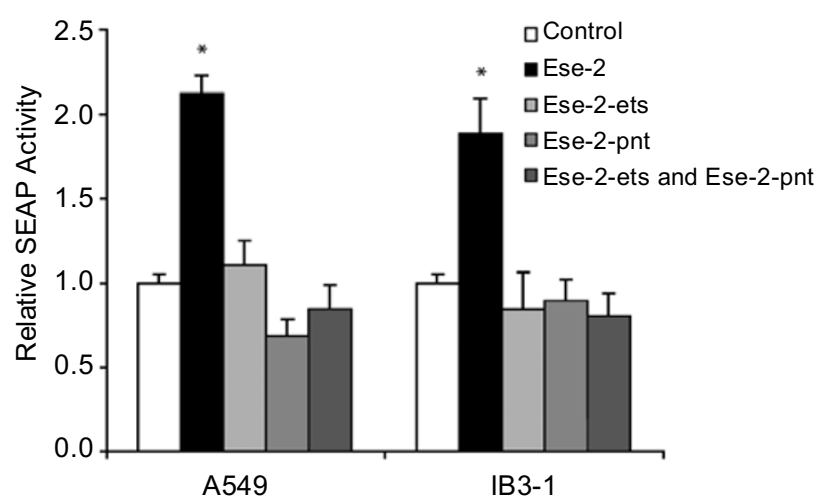

Fig. 1 Up-regulation of $K 18$ by Ese-2. A549 and IB3-1 cells were co-transfected with a $S E A P$ reporter construct and expression constructs Ese-2, Ese-2-ets, Ese-2-pnt, both Ese-2-ets and Ese-2-pnt, or the mammalian expression vector pcDNA3 (negative control). Transcription of $S E A P$ was driven by the $K 18$ minimal promoter with the $K 18$ first intron inserted upstream of the SEAP gene. The Ese-2 construct was designed to express full length Ese-2. The Ese2-ets construct was designed to express a protein containing the last 123 amino acids of Ese-2, which encodes the ETS domain. The Ese2-pnt construct was designed to express a protein containing the first 145 amino acids of Ese-2, which encodes the PNT domain. Media was processed for SEAP assays and the results of 3 separate experiments, each done in triplicate, are shown as Mean $\pm \mathrm{SE}$. The negative control was arbitrarily assigned a value of 1 , and all other data was normalized to this value. Bars represent SE. ANOVA was performed to establish statistical significance between means. Data with a significantly different mean is marked with a $\operatorname{star}(*),(P<0.05$, Dunnet two-sided test).

of IB3-1 lung cystic fibrosis cells (ATCC JHU-52) were grown in LHC-8 medium (Biofluids, Rockville, MD) supplemented with 5\% fetal bovine serum. Cotransfections of partially confluent cells (50$80 \%$ ) were carried out with $0.5 \mu \mathrm{g}$ of secreted alkaline phosphatase (SEAP) reporter gene plasmid DNA (pK18EpiSEAP) [30], $0.5 \mu \mathrm{g}$ of expression vector DNA (pcDNA3, pcDNA3 Ese-2, pcDNA3 Ese2-ets, or pcDNA3 Ese-2-pnt), and $6 \mu 1$ of Lipofectamine ${ }^{\mathrm{TM}}$ Reagent (Invitrogen) per $1 \mathrm{ml}$ of media. Each $1 \mathrm{ml}$ of media was incubated with the cells for $24 \mathrm{~h}$, and then replaced with new media. The new media was collected $24 \mathrm{~h}$ after the change and assayed for SEAP activity according to the protocol of the Phospha-Light ${ }^{\mathrm{TM}}$ Chemiluminescent Reporter Assay for Secreted Alkaline Phosphatase (Tropix, Bedford, MA).

\section{Electrophoresis Mobility Shift Assays (EMSAs)}

${ }^{32} \mathrm{P}$-labelled large DNA fragments and double-stranded oligonucleotide probes were used in the binding reactions at $10,000 \mathrm{cpm}$. Binding reactions were performed in $10 \mathrm{mM}$ Tris- $\mathrm{HCl}(\mathrm{pH} 8.0), 50 \mathrm{mM}$ $\mathrm{NaCl}, 1 \mathrm{mM}$ EDTA, $10 \mu \mathrm{g}$ BSA, $50 \mathrm{ng}$ poly(dI-dC), $200 \mathrm{ng}$ Herring testes carrier DNA, and $3 \mathrm{mM}$ dithiothreitol. Probes and the indicated amounts of bacterial expressed and purified Ese-2, Ese-2-ets, and Ese-2-pnt proteins were added to the reactions and incubated at 
A

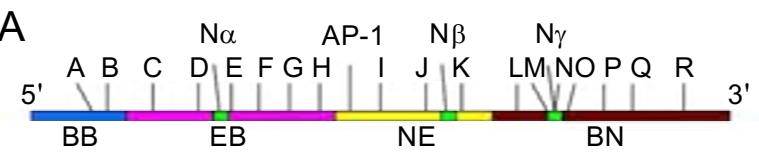

$\mathrm{B}$

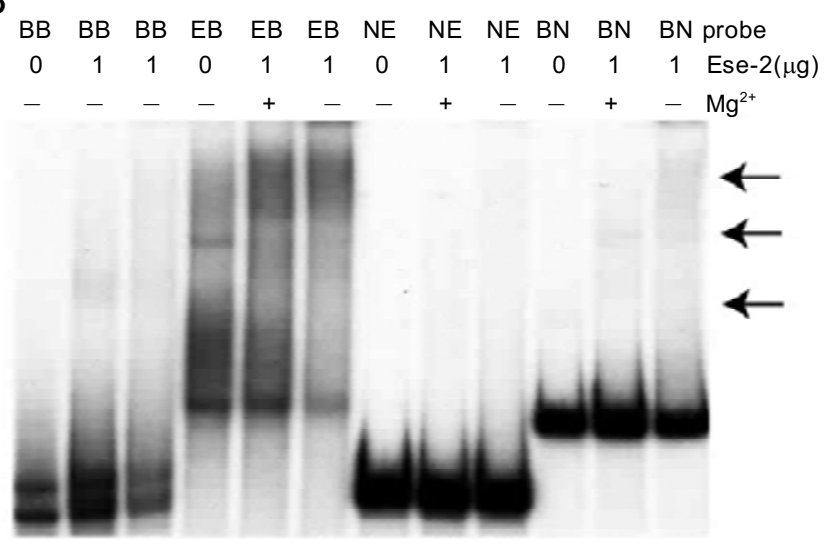

Fig. 2 Full length Ese-2 cannot efficiently bind the first intron of K18. (A) Schematic diagram of the first intron of K18 showing the four ${ }^{32} \mathrm{P}$-labelled DNA fragments that span the intron. (B) Electrophoresis mobility shift assay using DNA fragments BB, EB, NE, and $\mathrm{BN}\left(1 \times 10^{4} \mathrm{cpm}\right.$ each). Each DNA fragment was incubated with $1 \mu \mathrm{g}$ full length Ese-2 protein that was expressed and purified from E. coli. Arrows indicate regions of possible shift with EB and BN DNA fragments.

room temperature for $15 \mathrm{~min}$ before loading on low ionic strength $6 \%$ polyacrylamide gels, containing $0.5 \times$ TBE buffer $(0.045 \mathrm{M}$ Trisborate, $1 \mathrm{mM}$ EDTA).

\section{RESULTS}

Transcriptional regulation of $K 18$ by Ese-2 in lung epithelial cells

A549 and IB3-1 cells were cotransfected with a SEAP reporter construct, pK18EpiSEAP, and either pcDNA3, pcDNA3 Ese-2, pcDNA3 Ese-2-ets, pcDNA3 Ese-2-pnt, or both pcDNA3 Ese-2-ets and pcDNA3 Ese-2-pnt, to determine the effect of Ese- 2 on gene expression when interacting with the first intron of K18 (Fig. 1). Both A549 and IB3-1 cells were human lung epithelial origin. We found that wild type Ese-2 was able to significantly upregulate the expression of $K 18$ by approximately 2-fold, while the truncated versions of Ese-2, Ese-2-ets and Ese-2-pnt, resulted in levels of expression no different from those seen in the controls as determined by ANOVA.

Identifying the molecular interactions between Ese-2 and the large DNA fragments spanning the first intron of $K 18$

The cotransfection experiments demonstrated that Ese2 is able to interact with the first intron of $K 18$ to upregulate
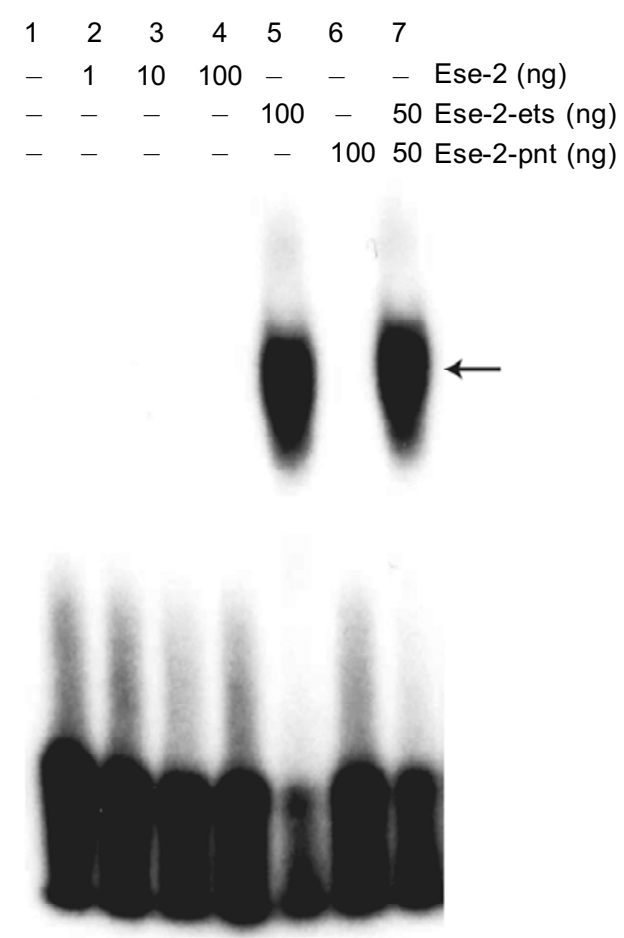

Fig. 3 Ese-2-ets, but not full length Ese-2, binds the E74 EBS. Lane 1, oligonucleotide $\left(1 \times 10^{4} \mathrm{cpm}\right)$ only; Lane $2,1 \mathrm{ng}$ wild type Ese-2; Lane 3, 10 ng wild type Ese-2; Lane 4, 100 ng wild type Ese-2; Lane 5, 100 ng Ese-2-ets; Lane 6,100 ng Ese-2-pnt; Lane 7, 50ng Ese-2-ets + 50 ng Ese-2-pnt.

gene expression. The next step in characterizing this interaction was to determine which regions of the first intron of $K 18$ are bound by Ese-2. To test this, EMSAs were performed with full length Ese-2, purified under native conditions, and 4 large DNA fragments that collectively span the first intron of $K 18$ (Fig. 2). These fragments were used to narrow down the interacting region (s). We detected weak complex formation only when a large amount of Ese-2 $(1 \mu \mathrm{g})$ was used in the EMSAs (Fig. 2), suggesting that full length Ese-2 alone may not be able to efficiently bind DNA. From this experiment it cannot be determined with certainty whether interactions are occurring between Ese-2 and any of the large DNA fragments.

\section{Investigating the DNA binding efficiency of Ese-2}

EMSAs with full length Ese-2 and the E74 oligonucleotide were performed and we found that Ese-2 did not bind the probe (Fig. 3). This E74 oligonucleotide contains the Drosophila E74 Ets binding site, and has previously been shown to bind to multiple Ets family members [36]. Since the PNT domain of Ese-2 has previously been sug- 
Tab. 1 Oligonucleotides used in EMSAs.

\begin{tabular}{|c|c|c|}
\hline Oligonucleotide & Sequence of top strand (5'-3') & Sequence of bottom strand (5'-3') \\
\hline A & ccAATGACGGAAAGAGGCAc & gTGCCTCTTTCCGTCATTgg \\
\hline $\mathrm{B}$ & GTGGTTATGGAATGACGGTC & GACCGTCATTCCATAACCAC \\
\hline $\mathrm{C}$ & GCGCGGAT $\underline{\text { GAAAATCCAGG }}$ & CCTGGATTTCCATCCGCGC \\
\hline $\mathrm{D}$ & СТCTCCTGGGAAAGAGCCCTC & GAGGGCTCTTTCCCAGGAGAG \\
\hline $\mathrm{E}$ & GAGAGGGGGAAGGGGACAG & CTGTCCCCTTCCCCCTCTC \\
\hline $\mathrm{F}$ & CTTTACAGAGGAAGTGGACAG & CTGTCCACTTCCTCTGTAAAG \\
\hline $\mathrm{G}$ & GGAGGTAA $\overline{\text { GGAAAGGCCTG }}$ & CAGGCCTTTCCTTACCTCC \\
\hline $\mathrm{H}$ & GCGTCTGGCGGAATGGGGAC & GTCCCCATTCCGCCAGACGC \\
\hline I & СТCCCAAAGGAAGGCCTCTTG & CAAGAGGCCTTCCTTTGGGAG \\
\hline $\mathrm{J}$ & GTGCACTAGGGAAAAAATGCC & GGCATTTTTTCCCTAGTGCAC \\
\hline $\mathrm{K}$ & GAGGGCCAGGAAGAGGACTTG & CAAGTCCTCTTCCTGGCCCTC \\
\hline $\mathrm{L}$ & CCTCTTGGGAAGCCTCAGC & GCTGAGGC $\overline{\text { TTCCCAAGAGG }}$ \\
\hline M & GGATCTGGGAATCCAGGTCC & GGACCTGGATTCCCAGATCC \\
\hline $\mathrm{N}$ & CGATCCAGGAAAGGAGGATCG & CGATCCTCCTTTCCTGGATCG \\
\hline $\mathrm{O}$ & CGAAGGAGGGAATGGGGTGG & CCACCСCATTCССТССТTCG \\
\hline $\mathrm{P}$ & GGTCCCAGGAATAGCCAGAGG & СCTCTGGCTATTCCTGGGACC \\
\hline Q & GGACCAGGAAGTTTTCACTAGG & CCTAGTGAAAACTTCCTGGTCC \\
\hline $\mathrm{R}$ & GCTAT TCATGGAACAACCTCTC & GAGAGGTTGTTCCATGAATAGC \\
\hline E74 & TCGAGTAACCGGAAGTAACTCAG & CTGAGTTACTTCCGGTTACTCGA \\
\hline
\end{tabular}

Note: Core recognition sequence in oligonucleotides A-R, listed in the order they appear in the first intron of K18 and oligonucleotide E74 are underlined; small font indicates bases that were introduced to avoid more than one core sequence in an oligonucleotide.

$A$

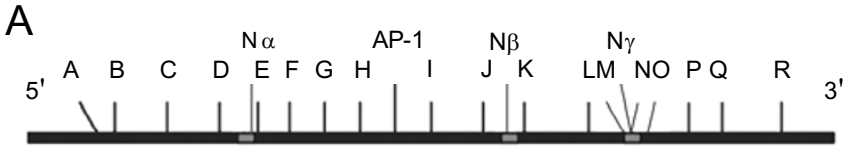

B

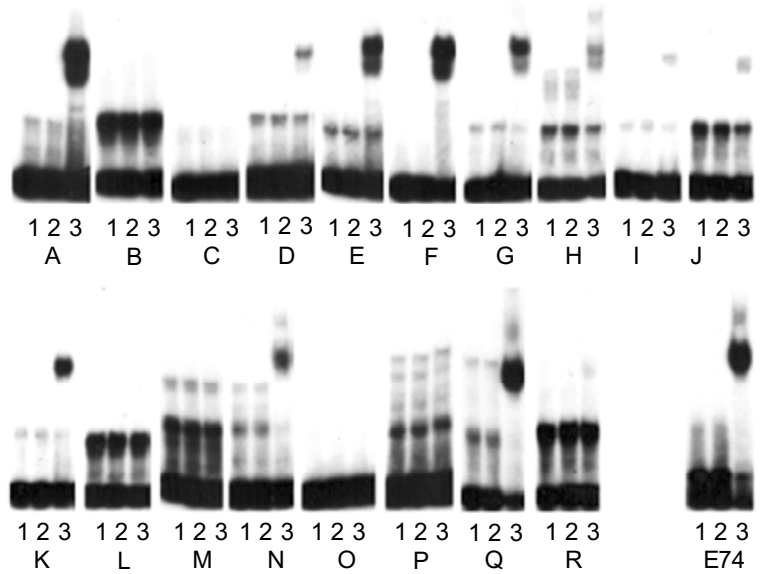

Fig. 4 Ese-2-ets selectively binds EBSs within the first intron of K18. (A) Schematic diagram of the first intron of K18. Negative regulatory elements $\left(\mathrm{N}_{\alpha}, \mathrm{N}_{\beta}, \mathrm{N}_{\gamma}\right)$ are indicated in grey. EBS locations corresponding to oligonucleotides A-R used in gel shift experiments are indicated. (B) Electrophoresis mobility shift assays. Each doublestranded oligonucleotide (K18 oligonucleotides A-R or E74) was incubated with or without (see lane descriptions) $100 \mathrm{ng}$ Ese-2-ets $E$. coli expressed and purified protein. Lane 1, oligonucleotide $\left(1 \times 10^{4}\right.$ cpm) only; Lane 2, $100 \mathrm{ng}$ wild type Ese-2; Lane 3, $100 \mathrm{ng}$ Ese-2-ets. gested to interfere with the DNA-binding abilities of the ETS domain [6], we created two truncated versions of the protein to use in EMSAs: Ese-2-ets, which expresses only the ETS domain of Ese-2 (the protein product of pET28a-Ese-2-ets); and Ese-2-pnt, which expresses only the PNT domain of Ese-2 (the protein product of pET28a.Ese-2-pnt). We then performed EMSAs with Ese2-ets and Ese-2-pnt and the E74 oligonucleotide (Fig. 3). We found that Ese-2-pnt did not bind E74. Ese-2-ets, however, was able to bind the oligonucleotide quite strongly, and its binding ability was not deterred by the presence of the PNT domain protein, Ese-2-pnt, when acting in trans. We used Ese-2-ets for the remaining gel shift experiments.

\section{Identifying a consensus recognition sequence of Ese-2 using DNA oligonucleotides containing the EBSs of $K 18$ intron 1}

Ese-2 has been described to bind to an EBS with a core of 5'-GGAA-3' [6, 11]. This implies that, for Ese-2, there are 18 possible EBSs within the first intron of $K 18$ (Fig. 4). To determine if Ese-2 is able to bind any of these putative EBSs we performed gel shift experiments with Ese-2-ets and the synthesized oligonucleotides (Tab. 1) containing one of each of the 18 possible EBSs as well as the sequence surrounding the EBSs. We found that Ese-2-ets 


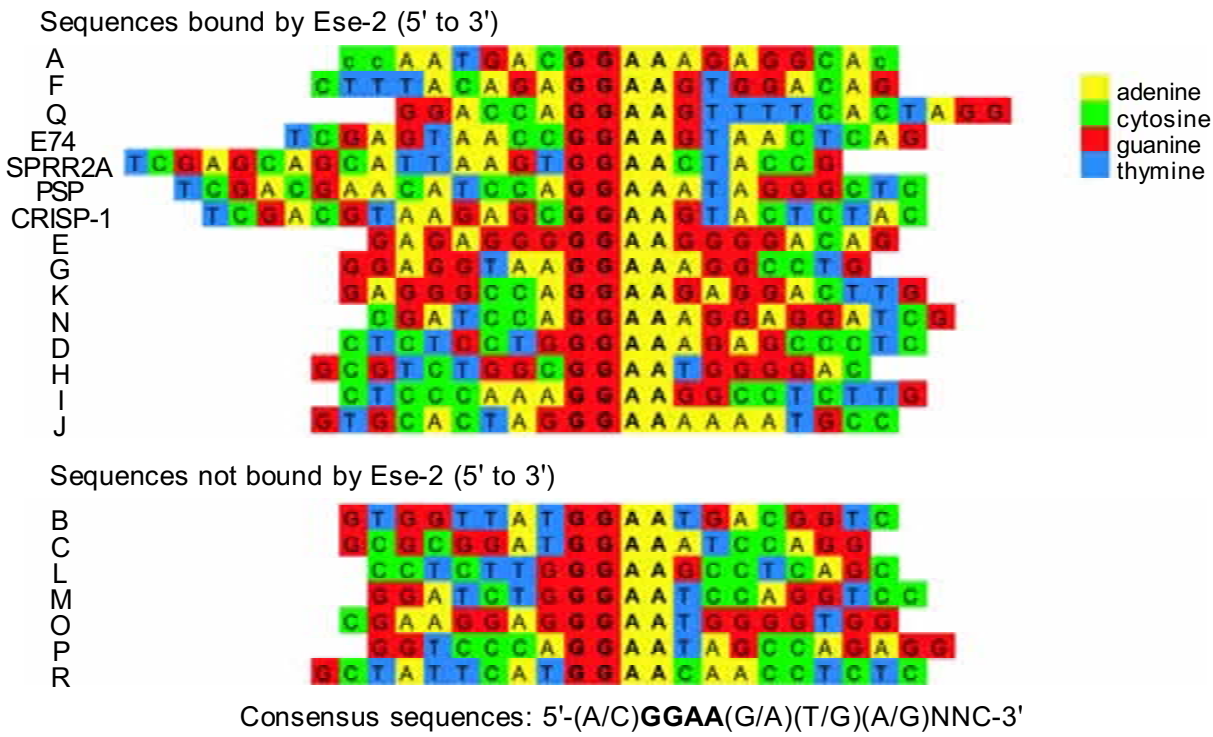

Fig. 5 Determination of Ese-2-ets consensus target sequence. All sequences were tested in this study except for SPRR2A, PSP, and CRISP-1, which were tested in another study [10]. Sequences were analyzed to determine a putative consensus sequence recognized by Ese-2-ets. This sequence was determined to be 5'-(A/C)GGAA(A/G)(G/T)(A/G)NNC-3'.

bound with the highest strength to oligonucleotides A, F, $\mathrm{Q}$, and E74, intermediate strength to oligonucleotides E, $\mathrm{G}, \mathrm{K}$, and $\mathrm{N}$, and bound weakly to oligonucleotides $\mathrm{D}, \mathrm{H}$, I, and J (Fig. 4). Ese-2-ets did not bind oligonucleotides B, C, L, M, O, P, or R, which shows that Ese-2-ets does bind DNA in a sequence specific manner. From these data, it can be determined that Ese-2-ets prefers the binding sequence 5'-(A/C)GGAA(A/G)(G/T)(A/G)NNC-3' (Fig. 5).

\section{DISCUSSION}

$K 18$ gene expression is actively regulated by the first intron of the gene $[32,33,35]$. There are multiple EBSs within the first intron, some of which have been shown to be involved in gene regulation [31-33], and Ese-2 is one Ets factor for which these sites may be targets. To elucidate whether Ese-2 is able to regulate $K 18$ gene expression through interaction with the first intron, cotransfection experiments, with A549 lung carcinoma cells and IB3-1 lung cystic fibrosis cells, and reporter gene assays were performed. The cells were cotransfected with a reporter/ target plasmid, pK18EpiSEAP, and an effector plasmid, either pcDNA3 (negative control), pcDNA3 Ese-2 (wild type Ese-2), pcDNA3·Ese-2-ets (Ese-2 ETS domain protein), pcDNA3 Ese-2-pnt (Ese-2 PNT domain protein), or pcDNA3 Ese-2-ets and pcDNA3'Ese-2-pnt together (Fig. 1). The reporter/target plasmid is designed so that the expression of the reporter gene, $S E A P$, will be upregulated only if Ese- 2 transactivates the promoter by binding the first intron of $K 18$. Ese- 2 up-regulated the expres- sion of SEAP significantly compared to the control. The level of up-regulation may be underestimated in our experiment since low endogenous levels of Ese- 2 expression could contribute to reporter up-regulation in the control (Fig. 1). In contrast, the two truncated proteins, Ese2-ets and Ese-2-pnt, resulted in levels of SEAP expression equal to the negative control level. This indicates that the ETS and PNT domains alone are not able to upregulate K18 gene expression. We also performed a cotransfection with both the truncated proteins to determine if they could act in trans to upregulate gene expression. When separated, the two domains could not upregulate expression, suggesting that Ese-2 function depends on the two domains being physically linked.

Gel shift experiments were performed to identify the site(s) of interaction between the first intron of $K 18$ and Ese-2. Wild type Ese-2 was not able to bind any of the four large DNA fragments of the first intron of $K 18$ (Fig. 2). Oettgen et al [6] previously reported that wild type Ese-2 cannot efficiently bind DNA in vitro, and they suggest that this is due to interference by the PNT domain. We then tested the binding efficiency of wild type Ese-2 using the E74 DNA oligonucleotide (Fig. 3). Truncated Ese-2 mutant proteins, Ese-2-ets (representing the Ets domain of Ese-2) and Ese-2-pnt (representing the PNT domain of Ese-2), were also used in this experiment. We found that the full length Ese-2 did not efficiently bind to the oligonucleotide, however the efficiency was greatly increased when only the ETS domain protein was used (Fig. 3). It 
was also determined that the PNT domain protein, Ese-2pnt, did not interfere with the DNA binding ability of Ese2-ets (Fig. 3) when it was provided in trans.

Ese-2-ets was used in gel shift experiments to identify which EBSs within the first intron of $K 18$ were interacting with the protein as well as to determine a putative DNA consensus recognition sequence for Ese-2. Ese-2ets was able to bind 11 of the possible $18 \mathrm{~K} 18$ intron 1 EBSs that were identified by their 5'-GGAA-3' core (Fig. 4), a core region which has been shown to be preferable for Ese- 2 binding $[6,11]$. Ese-2-ets bound with the highest strength to oligonucleotides A, F, Q, and E74, intermediate strength to oligonucleotides $\mathrm{E}, \mathrm{G}, \mathrm{K}$, and N, and bound weakly to oligonucleotides D, H, I, and J (Fig. 4), and did not bind oligonucleotides $\mathrm{B}, \mathrm{C}, \mathrm{L}, \mathrm{M}, \mathrm{O}, \mathrm{P}$, or R, which shows that Ese-2-ets binds DNA in a sequence specific manner. The putative DNA recognition sequence for Ese-2-ets, 5'-(A/C)GGAA(A/G)(G/T)(A/G)NNC-3' (Fig. 5) can now be applied to identify putative Ese-2 target genes.

Collectively, the gel shift experiments and the cotransfection experiments suggest that other proteins must also affect the DNA-binding ability of Ese- 2 in order to prevent the inhibition of DNA-binding. This has been previously suggested by Oettgen et al [6] and concurs with the data shown for most other Ets factors [27]. It was shown in the gel shift experiments that Ese-2 does not efficiently bind DNA sequences in the presence of the PNT domain, yet in the cotransfection experiments, it was shown that wild type Ese- 2 was able to bind the first intron of $K 18$ to upregulate gene expression (Fig. 1). Therefore, in cultured cells, other proteins must aid the protein-DNA interaction by interacting with a region of Ese-2, most likely the PNT domain, to prevent it from interfering with the ETS domain and the DNA-binding ability of the protein.

On the basis of our results, we propose that Ese-2 upregulates the expression of $K 18$ by interacting with EBSs located in the first intron of the gene. We suggest that for this to occur, Ese-2 forms a complex with one or more other proteins through the PNT domain to allow the ETS domain to interact with the target gene. Since Ese-2 is epithelium-specific and able to regulate an epitheliumspecific gene, $K 18$, it may play a role, together with other factors, in epithelial differentiation during development or epithelial regeneration.

\section{ACKNOWLEDGEMENTS}

We thank Drs. A. Keith Tanswell, James Ellis, David R. Koehler and Mingyao Liu for helpful suggestions during manuscript preparation. This work was supported by operating grants from the Canadian Institutes of Health Research, the Canadian Cystic Fibrosis Foundation (to
J.H.), and the Foundation Fighting Blindness-Canada (to J.H.). DY held a Restracomp award from the Hospital for Sick Children Research Institute, and J.H. is a CCFF Scholar and holds a Premier's Research Excellence Award of Ontario Canada.

\section{Received, Mar 1, 2005}

Revised, Apr 5, 2005

Accepted, Apr 16, 2005

\section{REFERENCES}

1 Nunn MF, Seeburg PH, Moscovici C, et al. Tripartite structure of the avian erythroblastosis virus E26 transforming gene. Nature 1983; 306:391-5.

2 Watson DK, Ascione R, Papas TS. Molecular analysis of the Ets genes and their products. Crit Rev Oncog 1990; 1:409-36.

3 Papas TS, Watson DK, Sacchi N, et al. Ets family of genes in leukemia and down syndrome. Am J Med Genet Suppl 1990; 7: 251-61.

4 Bhat NK, Komschlies KL, Fujiwara S, et al. Expression of Ets genes in mouse thymocyte subsets and t cells. J Immunol 1989; 142:672-8.

5 Kola I, Brookes S, Green AR, et al. The ets1 transcription factor is widely expressed during murine embryo development and is associated with mesodermal cells involved in morphogenetic processes such as organ formation. Proc Natl Acad Sci U S A 1993; 90:7588-92.

6 Oettgen P, Kas K, Dube A, et al. Characterization of Ese-2, a novel Ese-1-related Ets transcription factor that is restricted to glandular epithelium and differentiated keratinocytes. J Biol Chem 1999; 274:29439-52.

7 Oettgen P, Alani RM, Barcinski MA, et al. Isolation and characterization of a novel epithelium-specific transcription factor, ESE1, a member of the ETS family. Mol Cell Biol 1997; 17:4419-33.

8 Tugores A, Le J, Sorokina I, et al. The epithelium-specific ETS protein EHF/ESE-3 is a context-dependent transcriptional repressor downstream of mapk signaling cascades. J Biol Chem 2001; 276:20397-406.

9 Thomas RS, Ng AN, Zhou J, et al. The elf group of ETS-related transcription factors. ELF3 and ELF5. Adv Exp Med Biol 2000; 480:123-8.

10 Oettgen P, Barcinski M, Boltax J, et al. Genomic organization of the human ELF3 (ESE-1/ESX) gene, a member of the ets transcription factor family, and identification of a functional promoter. Genomics 1999; 55:358-62.

11 Zhou J, Ng AY, Tymms MJ, et al. A novel transcription factor, ELF5, belongs to the ELF subfamily of ETS genes and maps to human chromosome $11 \mathrm{p} 13-15$, a region subject to loh and rearrangement in human carcinoma cell lines. Oncogene 1998; 17: 2719-32.

12 Graves BJ, Petersen JM. Specificity within the ets family of transcription factors. Adv Cancer Res 1998; 75:1-55.

13 Sementchenko VI, Watson DK. Ets target genes: Past, present and future. Oncogene 2000; 19:6533-48.

14 Sharrocks AD, Brown AL, Ling Y, et al. The ets-domain transcription factor family. Int J Biochem Cell Biol 1997; 29:137187.

15 Seth A, Ascione R, Fisher RJ, et al. The ets gene family. Cell 
Growth Differ 1992; 3:327-34.

16 Macleod K, Leprince D, Stehelin D. The Ets gene family. Trends Biochem Sci 1992; 17:251-6.

17 Wasylyk B, Hahn SL, Giovane A. The Ets family of transcription factors. Eur J Biochem 1993; 211:7-18.

18 Janknecht R, Nordheim A. Gene regulation by Ets proteins. Biochim Biophys Acta 1993; 1155:346-56.

19 Werner MH, Clore M, Fisher CL, et al. The solution structure of the human Ets-1-DNA complex reveals a novel mode of binding and true side chain intercalation. Cell 1995; 83:761-71.

20 Kodandapani R, Pio F, Ni CZ, et al. A new pattern for helix-turnhelix recognition revealed by the PU.1 Ets-domain-DNA complex. Nature 1996; 380:456-60.

21 O'Hagan RC, Tozer RG, Symons M, et al. The activity of the Ets transcription factor pea3 is regulated by two distinct mapk cascades. Oncogene 1996; 13:1323-33.

22 Rottinger E, Besnardeau L, Lepage T. A Raf/MEK/ERK signaling pathway is required for development of the sea urchin embryo micromere lineage through phosphorylation of the transcription factor Ets. Development 2004; 131:1075-87.

23 O'Neill EM, Rebay I, Tjian R, Rubin GM. The activities of two Ets-related transcription factors required for Drosophila eye development are modulated by the Ras/MAPK pathway. Cell 1994; 78:137-47.

24 Silverman ES, Baron RM, Palmer LJ, et al. Constitutive and cytokine-induced expression of the ets transcription factor Ese3 in the lung. Am J Respir Cell Mol Biol 2002; 27:697-704.

25 Galang CK, Muller WJ, Foos G, et al. Changes in the expression of many Ets family transcription factors and of potential target genes in normal mammary tissue and tumors. J Biol Chem 2004; 279:11281-92.

26 Verger A, Duterque-Coquillaud M. When Ets transcription factors meet their partners. Bioessays 2002; 24:362-70.
27 Li R, Pei H, Watson DK. Regulation of Ets function by protein -protein interactions. Oncogene 2000; 19:6514-23.

28 Klambt C. The Drosophila gene pointed encodes two Ets-like proteins which are involved in the development of the midline glial cells. Development 1993; 117:163-76.

29 Jousset C, Carron C, Boureux A, et al. A domain of TEL conserved in a subset of ETS proteins defines a specific oligomerization interface essential to the mitogenic properties of the TELPDGFR $\beta$ oncoprotein. Embo J 1997; 16:69-82.

30 Chow YH, O'Brodovich H, Plumb J, et al. Development of an epithelium-specific expression cassette with human DNA regulatory elements for transgene expression in lung airways. Proc Natl Acad Sci U S A 1997; 94:14695-700.

31 Oshima RG, Abrams L, Kulesh D. Activation of an intron enhancer within the keratin 18 gene by expression of c-fos and cjun in undifferentiated $\mathrm{f} 9$ embryonal carcinoma cells. Genes Dev 1990; 4:835-48.

32 Pankov R, Neznanov N, Umezawa A, et al. Ap-1, ets, and transcriptional silencers regulate retinoic acid-dependent induction of keratin 18 in embryonic cells. Mol Cell Biol 1994; 14:774457.

33 Umezawa A, Yamamoto H, Rhodes K, et al. Methylation of an Ets site in the intron enhancer of the keratin 18 gene participates in tissue-specific repression. Mol Cell Biol 1997; 17:4885-94.

34 Lennon G, Auffray C, Polymeropoulos M, et al. The i.M.A.G. E. Consortium: An integrated molecular analysis of genomes and their expression. Genomics 1996; 33:151-2.

35 Oshima RG, Baribault H, Caulin C. Oncogenic regulation and function of keratins 8 and 18. Cancer Metastasis Rev 1996; 15: 445-71.

36 Burtis KC, Thummel CS, Jones CW, et al. The Drosophila 74EF early puff contains E74, a complex ecdysone-inducible gene that encodes two Ets-related proteins. Cell 1990; 61:85-99. 